DOI:10.18276/sip.2016.45/2-20

\title{
Dorota Jankowska*
}

Agnieszka Majka**

Uniwersytet Rzeszowski

\section{ZMIANY W ZATRUDNIENIU W SEKTORZE USŁUG A ROZWÓJ GOSPODARCZY REGIONU}

\begin{abstract}
Streszczenie
W artykule podjęto próbę odpowiedzi na pytanie, czy istnieje relacja pomiędzy strukturą i dynamiką zatrudnienia w sektorze usługowym a rozwojem gospodarczym regionu. W celu określenia zmian, jakie zaszły w zatrudnieniu w usługach, posłużono się liniowymi modelami trendu, zaś stopień rozwoju wyznaczono za pomocą taksonomicznej metody grupowania obiektów. Empiryczny materiał liczbowy pochodził z Banku Danych Lokalnych GUS i dotyczył lat 2005-2013.
\end{abstract}

Słowa kluczowe: rozwój gospodarczy, zatrudnienie, sektor usługowy, trend, grupowanie taksonomiczne

\section{Wstęp}

Współczesne rozwinięte gospodarki charakteryzują się dominującą rolą sektora usług w wytwarzaniu PKB oraz w zatrudnieniu. PKB per capita jest z kolei najważniejszym wskaźnikiem mówiącym o rozwoju gospodarczym kraju czy regionu. Odpowiednia struktura zatrudnienia ma więc wpływ na ich sytuację ekonomiczną, decyduje o ich konkurencyjności, przyczyniając się w rezultacie do ich rozwoju.

* Adres e-mail: dorjan@univ.rzeszow.pl.

**Adres e-mail: amajka@univ.rzeszow.pl. 
Stąd też podjęto próbę odpowiedzi na pytanie, czy zmiana w strukturze i dynamice zatrudnienia w sektorach gospodarki, a w szczególności w sektorze usług, w poszczególnych województwach decyduje o ich rozwoju gospodarczym.

\section{Przeobrażenia w strukturze zatrudnienia a rozwój gospodarczy (usługowa opcja rozwoju gospodarczego)}

Klasyczna koncepcja podziału gospodarki na trzy sektory, którą posłużono się $\mathrm{w}$ niniejszym opracowaniu, została sformułowana w pierwszej połowie lat trzydziestych XX wieku przez A. Fishera (Kwiatkowski, 1980). W późniejszym czasie była modyfikowana przez wielu ekonomistów, wśród których wymienić należy między innymi: C. Clarka oraz J. Fourastiego. W myśl teorii tego ostatniego wraz z rozwojem gospodarczym maleje znaczenie sektora rolnictwa, czego wyrazem jest malejący udział tego sektora w ogólnym zatrudnieniu. Sektor przemysłowy na określonym etapie rozwoju gospodarczego wykazuje wzrost znaczenia w gospodarce, następnie pewną stabilizację, by w późniejszych etapach rozwoju gospodarczego zmniejszyć swoją pozycję w gospodarce. Natomiast sektor usługowy wykazuje w procesie rozwoju gospodarczego ustawiczną tendencję zwyżkową. W początkowych fazach wzrost znaczenia sektora usługowego dokonuje się kosztem dalszego spadku znaczenia rolnictwa, w fazach późniejszych zaś także kosztem przemysłu (Kwiatkowski, 1980).

Ewolucja współczesnej gospodarki następuje w kierunku serwicyzacji życia gospodarczego. W gospodarkach wielu krajów europejskich, w tym także Polski, ma miejsce systematyczny spadek zatrudnienia w sektorze rolniczym, a później przemysłowym na rzecz sektora usługowego. Mimo że sektor usług w Polsce skupia największą liczbę zatrudnionych, to sektor przemysłowy odgrywa w dalszym ciągu znaczącą rolę w strukturze zatrudnienia (Jankowska, Majka, 2012, 2013). Dynamiczny rozwój oraz wzrost znaczenia sektora usług w Polsce nastąpił po 1989 roku, a jego ekspansja staje się obecnie głównym wyznacznikiem tempa rozwoju gospodarczego kraju czy regionu.

\section{Materiał empiryczny i metodyka badań}

W niniejszym opracowaniu wykorzystano dane z Banku Danych Lokalnych GUS, do analizy których wykorzystano wskaźniki struktury, liniowe i wielomianowe 
funkcje trendu oraz taksonomiczną metodę grupowania obiektów. Przeprowadzona analiza dotyczyła lat 2005-2013.

Zgromadzone dane odnosiły się do odsetka zatrudnionych w sektorze rolniczym (sekcja A według PKD 2007), przemysłowym (sekcje B, C, D, E, F) łącznie z budownictwem (sekcja F) oraz sektorze usługowym (sekcje G-S) w poszczególnych województwach w latach 2005-2013. Sektor usługowy podzielono dodatkowo na 3 grupy:

a) handel hurtowy i detaliczny; naprawa pojazdów samochodowych, włączając motocykle; transport i gospodarka magazynowa; działalność związana z zakwaterowaniem i usługami gastronomicznymi; informacja i komunikacja (sekcje G-J);

b) działalność finansowa i ubezpieczeniowa; działalność związana z obsługą rynku nieruchomości (sekcje K, L);

c) działalność profesjonalna, naukowa i techniczna; działalność w zakresie usług administrowania i działalność wspierająca; administracja publiczna i obrona narodowa; obowiązkowe zabezpieczenia społeczne; edukacja; opieka zdrowotna i pomoc społeczna; działalność związana z kulturą, rozrywką i rekreacją; pozostała działalność usługowa (sekcje M-S).

Tradycyjne mierniki rozwoju gospodarczego są oparte na Systemie Rachunków Narodowych. Najczęściej stosowaną miarą poziomu rozwoju jest PKB uzupełniony innymi miernikami ekonomicznymi, gospodarczymi oraz miernikami demograficznymi i społecznymi. Do oceny rozwoju gospodarczego regionu wykorzystano następujące zmienne: PKB na jednego mieszkańca (w zł); udział wartości dodanej brutto W wartości dodanej brutto ogółem według grup sekcji PKD 2007 (w \%); produkcję energii elektrycznej na jednego mieszkańca (w MWh); drogi ekspresowe i autostrady na $100 \mathrm{~km}^{2}$ (w km); nakłady wewnętrzne na B+R na jednego mieszkańca (w zł); nakłady zewnętrzne na B+R na jednego mieszkańca (w zł); plony pszenicy (w dt·ha ${ }^{-1}$ ); spodziewaną długość życia mężczyzn i kobiet; udział ludności w wieku przedprodukcyjnym < 17 lat; udział ludności w wieku produkcyjnym; udział ludności w wieku poprodukcyjnym; odsetek osób zatrudnionych w B+R; odsetek przedsiębiorstw innowacyjnych z sektora usług; odsetek osób zatrudnionych w sektorach rolniczym, przemysłowym i w budownictwie oraz w usługach; stopę bezrobocia rejestrowanego (w \%); miesięczne wydatki na żywność i napoje bezalkoholowe na osobę (w zł); udział miesięcznych wydatków na żywność i napoje bezalkoholowe w wydatkach ogółem (na osobę w \%); zgony niemowląt na 1000 urodzeń żywych; liczbę lekarzy na 10 tys. osób; liczbę łóżek w szpitalu na 10 tys. osób; liczbę studentów na 10 tys. osób. 


\section{Zmiany $w$ strukturze i dynamice zatrudnienia $w$ ujęciu regionalnym w latach 2005-2013}

W strukturze zatrudnienia w Polsce dominuje sektor usługowy, następnie przemysłowy i budownictwo, najmniejszą zaś liczbę pracujących skupia sektor rolniczy (rysunek 1).

Rysunek 1. Struktura zatrudnienia w sektorach gospodarki w poszczególnych województwach - średnio w latach 2005-2013

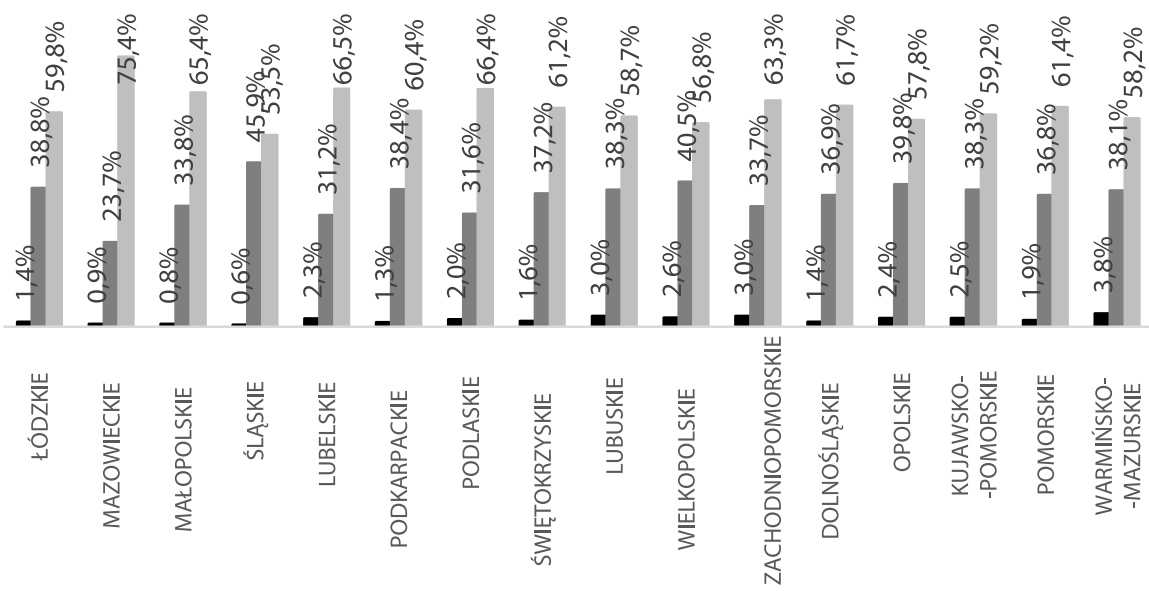

-ROLNICTWO DRZEMYSŁ, BUDOWNICTWO USŁUGI

Źródło: opracowanie własne na podstawie danych GUS.

Taka sytuacja występuje we wszystkich województwach naszego kraju, przy czym województwami o najwyższym odsetku zatrudnienia w sektorze usługowym są: mazowieckie, lubelskie, podlaskie, małopolskie. W województwach tych sektor przemysłowy skupia mniejszą $\mathrm{w}$ porównaniu z innymi województwami liczbę zatrudnionych.

Do województw o najmniejszym odsetku zatrudnionych w sektorze usługowym należą: śląskie, wielkopolskie, opolskie, warmińsko-mazurskie i lubuskie.

Jeśli chodzi o strukturę zatrudnienia w samym sektorze usługowym, to dominują sekcje M-S oraz w mniejszym stopniu G-J (rysunek 2). To, że największy odsetek pracujących zatrudniony jest w sekcjach $\mathrm{M}-\mathrm{S}$, wynika $\mathrm{z}$ faktu, iż w dużym stopniu wzrosło i dalej wzrasta gospodarcze znaczenie wiedzy. Poprzez zwiększa- 
nie zasobu pracowników wiedzy sektor usługowy wspiera tym samym gospodarkę opartą na wiedzy (GOW). Nauka wraz z zapleczem B+R, edukacja oraz działalność profesjonalna, naukowa i techniczna, które wchodzą do omawianej grupy sekcji, są uznawane za nośniki GOW. Pozostałe dwa nośniki GOW, czyli przemysł wysokiej techniki oraz technologie informatyczne, również nie mają szans na rozwój bez solidnego wsparcia usługowego (Kuczewska, 2007).

Największy odsetek zatrudnionych w sekcjach M-S występuje w województwach: opolskim, warmińsko-mazurskim, lubelskim i podlaskim. Z kolei w województwie mazowieckim dominuje zatrudnienie w sekcjach G-J związanych z handlem, transportem, informacją i komunikacją, usługami gastronomicznymi i hotelarskimi. Stosunkowo duże jest też zatrudnienie w sekcjach K-L (działalność finansowa, ubezpieczeniowa, rynek nieruchomości). W województwie wielkopolskim obie grupy sekcji (tj. M-S oraz G-J) skupiają podobny odsetek zatrudnionych. W województwie małopolskim sekcje G-J skupiają blisko 42\% zatrudnionych w usługach.

Rysunek 2. Struktura zatrudnienia w grupach sekcji w sektorze usługowym w poszczególnych województwach - średnio w latach 2005-2013
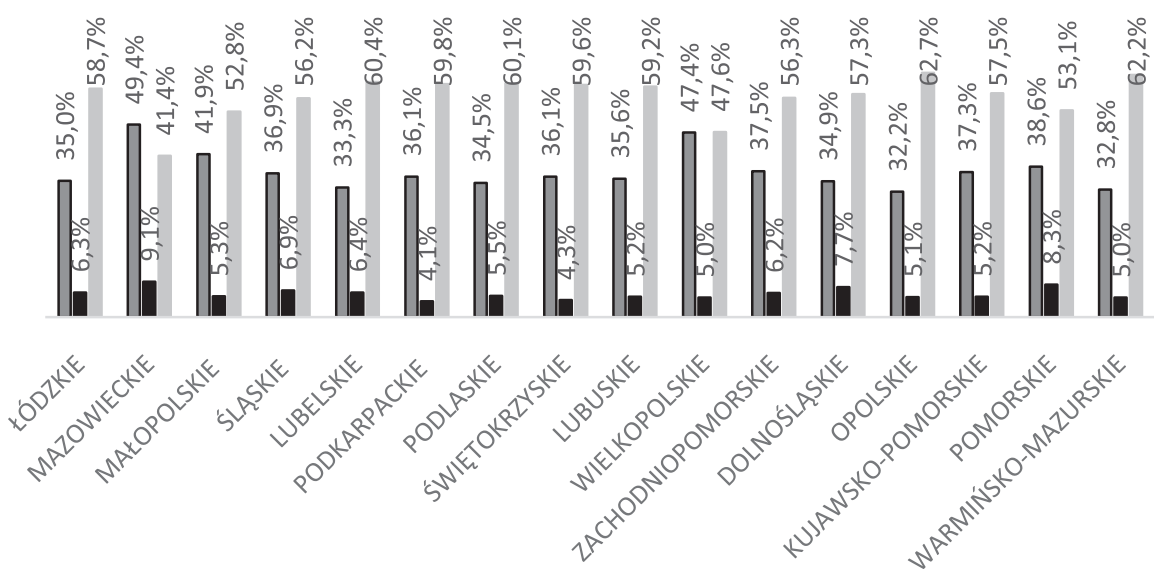

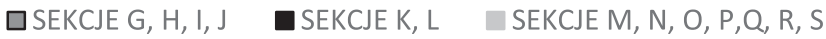

Źródło: opracowanie własne na podstawie danych GUS. 
Dynamikę zatrudnienia w sektorze usługowym scharakteryzowano za pomocą liniowych i wielomianowych funkcji tendencji rozwojowej. Zatrudnienie w sektorze usług ogółem (tabela 1) w województwach małopolskim, podlaskim, świętokrzyskim, lubuskim, dolnośląskim, opolskim, pomorskim spadało do lat 2007-2008, w warmińsko-mazurskim do 2009 roku, a następnie do końca badanego okresu wykazywało tendencję wzrostową. W województwach: łódzkim, mazowieckim, podkarpackim, wielkopolskim i kujawsko-pomorskim zatrudnienie w sektorze usług rosło systematycznie w całym badanym okresie. Największy wzrost zatrudnienia zanotowano w województwach: wielkopolskim (o 0,48 p.p.), mazowieckim (o 0,45 p.p.) oraz łódzkim (o 0,33 p.p.). Jedynie w województwie lubelskim zatrudnienie w usługach w latach 2005-2013 malało średnio o 0,16 p.p. z roku na rok.

Zmiany zatrudnienia w sektorze usługowym w województwie śląskim i zachodniopomorskim charakteryzowały się dużą nieregularnością, toteż funkcją, która te zmiany opisuje, jest wielomian stopnia 5.

Tabela 1. Funkcje trendu dla zatrudnienia w sektorze usługowym w poszczególnych województwach w latach 2005-2013

\begin{tabular}{|c|c|c|}
\hline & Równanie funkcji trendu & Dopasowanie \\
\hline 1 & 2 & 3 \\
\hline łódzkie & $y=58,16+0,33 x$ & $91,9 \%$ \\
\hline mazowieckie & $y=73,22+0,45 x$ & $79,4 \%$ \\
\hline małopolskie & $\begin{array}{l}y=65,47-0,35 x+0,05 x^{2} \\
\text { teoret.p.przeg.: } 2007 / 2008\end{array}$ & $74,4 \%$ \\
\hline śląskie & $\begin{aligned} y= & 52,4+2,49 x-1,78 x^{2}+0,51 x^{3}-0,06 x^{4}+3 \mathrm{E}-03 x^{5} \\
& \text { teoret.p.przeg.: } 2005 / 2006 ; 2007 ; 2010 ; 2012\end{aligned}$ & $85,4 \%$ \\
\hline lubelskie & $y=67,27 \%-0,16 x$ & $59,2 \%$ \\
\hline podkarpackie & $y=59,14+0,24 x$ & $66,4 \%$ \\
\hline podlaskie & $\begin{array}{l}y=67,19-0,59 x+0,07 x^{2} \\
\text { teoret.p.przeg.: } 2008 \mathrm{r} .\end{array}$ & $52,8 \%$ \\
\hline świętokrzyskie & $\begin{array}{l}y=61,70-0,59 x+0,08 x^{2} \\
\text { teoret.p.przeg.: } 2008 \mathrm{r} .\end{array}$ & $75,3 \%$ \\
\hline lubuskie & $\begin{array}{c}y=60,22-1,06+0,12 x^{2} \\
\text { teoret.p.p.rzeg.: } 2008 \mathrm{r} .\end{array}$ & $73,9 \%$ \\
\hline wielkopolskie & $y=54,42+0,48 x$ & $91,1 \%$ \\
\hline zachodniopomorskie & $\begin{aligned} y= & 60,18+6,59 x-4,51 x^{2}+1,22 x^{3}-0,14 x^{4}+6 \mathrm{E}-03 x^{5} \\
& \text { teoret.p.przeg.: } 2005 / 2006 ; 2007 ; 2010 ; 2012\end{aligned}$ & $78,4 \%$ \\
\hline dolnośląskie & $\begin{array}{l}y=61,49-0,55 x+0,09 x^{2} \\
\text { teoret.p.przeg.: } 2007 \mathrm{r} .\end{array}$ & $85,0 \%$ \\
\hline
\end{tabular}




\begin{tabular}{|l|c|c|}
\hline \multicolumn{1}{|c|}{1} & 2 & 3 \\
\hline opolskie & $\begin{array}{c}y=57,49-0,21 x+0,04 x^{2} \\
\text { teoret.p.przeg.: } 2007 \mathrm{r} .\end{array}$ & $89,9 \%$ \\
\hline kujawsko-pomorskie & $y=58,07+0,23 x$ & $82,6 \%$ \\
\hline pomorskie & $\begin{array}{r}y=61,67-0,81 x+0,12 x^{2} \\
\text { teoret.p.przeg.: } 2007 \mathrm{r} .\end{array}$ & $90,7 \%$ \\
\hline $\begin{array}{l}\text { warmińsko- } \\
\text { mazurskie }\end{array}$ & $\begin{array}{r}y=60,32-1,03 x+0,10 x^{2} \\
\text { teoret.p.przeg.: } 2009 \mathrm{r} .\end{array}$ & $84,7 \%$ \\
\hline
\end{tabular}

Źródło: opracowanie własne na podstawie danych GUS.

\section{Taksonomiczna ocena rozwoju gospodarczego w regionach}

W wyniku doboru zmiennych diagnostycznych do analizy taksonomicznej spośród zaproponowanych początkowo 26 wyeliminowano 9, zostały one bowiem uznane za quasi-stałe (założono $V<7 \%$ ), czyli miały niską skuteczność do dyskryminowania obiektów lub były nośnikami podobnych informacji (założono $\left.r^{*}=0,85\right)$. W rezultacie zestaw zmiennych diagnostycznych to zbiór 17 zmiennych, z których na podstawie kryteriów merytorycznych 10 uznano za stymulanty, zaś 7 za destymulany:

1. PKB na jednego mieszkańca [zł];

2. udział wartości dodanej brutto w wartości dodanej brutto ogółem według grup sekcji PKD 2007 r. [\%]:
a) rolnictwo;
b) przemysł, budownictwo;
c) usługi;

3. produkcja energii elektrycznej na jednego mieszkańca [MWh];

4. drogi ekspresowe i autostrady na $100 \mathrm{~km}^{2}[\mathrm{~km}]$;

5. plony pszenicy $\left[\mathrm{dt} \cdot \mathrm{ha}^{-1}\right]$;

6. udział ludności w wieku poprodukcyjnym;

7. odsetek przedsiębiorstw innowacyjnych $\mathrm{z}$ sektora usług;

8. odsetek osób zatrudnionych w sektorach:

a) rolniczym;

b) usługowym;

9. stopa bezrobocia rejestrowanego [\%];

10. udział miesięcznych wydatków na żywność i napoje bezalkoholowe w wydatkach ogółem na osobę [\%]; 
11. zgony niemowląt na 1000 urodzeń żywych;

12. liczba lekarzy na 10 tys. osób;

13. liczba łóżek w szpitalu na 10 tys. osób;

14. liczba studentów na 10 tys. osób.

W kolejnym kroku dokonano unitaryzacji zmiennych, dzięki czemu zrealizowano jeden z naczelnych postulatów analizy taksonomicznej, jakim jest porównywalność zmiennych. W kolejnym kroku wyznaczono odległości euklidesowe każdego obiektu (województwa) od wzorca oraz wyznaczono syntetyczne taksonomiczne miary rozwoju Hellwiga $d_{i}^{2}$. W celu unormowania zmiennej syntetycznej skonstruowano względny miernik rozwoju ${ }^{3}$, który przyjmuje z reguły wartości z przedziału [0;1] (tabela 2). Im wartość względnego syntetycznego miernika jest bliższa jedności, tym w mniejszym stopniu poziom rozwoju danego obiektu różni się od obiektu modelowego (Nowak, 1990).

Obliczone wartości mierników syntetycznych wykorzystano do ustalenia podziału województw na grupy typologiczne według schematu klasyfikacyjnego:

- klasa I (wysoki poziom ocenianego zjawiska): $z_{i} \geq \bar{z}+S_{z}$,

- klasa II (średni-wyższy poziom ocenianego zjawiska): $\bar{z} \leq z_{i}<\bar{z}+S_{z}$,

- klasa III (średni-niższy poziom ocenianego zjawiska): $\bar{z}-S_{z} \leq z_{i}<\bar{z}$,

- klasa IV (niski poziom ocenianego zjawiska): $z_{i}<\bar{z}-S_{z}$.

W 2013 roku wysokim stopniem rozwoju gospodarczego charakteryzowało się tylko województwo mazowieckie. Siedem województw charakteryzowało się średnim-wyższym stopniem rozwoju, 4-średnim-niższym i 4-niskim. Klasyfikacja prawie wszystkich województw (oprócz dolnośląskiego) była taka sama w latach 2005 i 2013. W wyniku przeprowadzonej taksonomicznej klasyfikacji województw uzyskano ich ranking pod względem rozwoju gospodarczego. Wśród województw zajmujących ostatnie miejsca $\mathrm{w}$ rankingu rozwoju gospodarczego znajdują się aż 4 województwa polski wschodniej (,wschodnia ściana płaczu” objęta Programem Rozwój Polski Wschodniej): podlaskie - miejsce 13, warmińsko-mazurskie-miejsce 14, świętokrzyskie - miejsce 15 i podkarpackie - miejsce 16. We wszystkich tych województwach stopień rozwoju gospodarczego oceniono jako niski. Trzy województwa zachowały w rankingu w 2013 roku miejsce z roku 2005: mazowieckie,

1 Dla stymulant: $z_{i k}=\frac{x_{i k}-\min _{i}\left[x_{i k}\right]}{\max _{i}\left\{x_{i k}\right\}-\min _{i}\left[x_{i k}\right\}}$;

Dla destymulant: $\quad z_{i k}=\frac{\max _{i}\left[x_{i k}\right]-x_{i k}}{\max _{i}\left[x_{i k}\right]-\min _{i}\left[x_{i k}\right]}$.

$2 d_{i}=\left[\sum_{i=1}^{k}\left(z_{i k}-1\right)^{2}\right]^{1 / 2}$

$3 z_{i}=1-\frac{d_{i}}{d_{0}}$, gdzie: $d_{0}=\bar{d}+2 S_{d}$ 
śląskie i podlaskie. Sześć województw spadło w rankingu - największy spadek, aż o 5 miejsc, miał miejsce w województwie dolnośląskim. Siedem województw podniosło swą pozycję w rankingu rozwoju gospodarczego - pozycja województwa zachodniopomorskiego wzrosła aż o 3 miejsca. Pod względem rozwoju gospodarczego liderem jest województwo mazowieckie. Zajmowało ono pierwsze miejsce zarówno w roku 2005, jak i 2013. W czołówce województw plasują się również województwa: małopolskie, pomorskie i zachodniopomorskie.

Tabela 2. Wartości syntetycznych mierników rozwoju oraz klasyfikacja województw pod względem stopnia rozwoju gospodarczego w latach 2005 i 2013

\begin{tabular}{|c|c|c|c|c|}
\hline Województwo & $\begin{array}{l}\text { Wartość } \\
\text { syntetycznego } \\
\text { miernika } \\
\text { rozwoju } \\
2005\end{array}$ & $\begin{array}{l}\text { Klasyfikacja } \\
\text { pod względem } \\
\text { stopnia rozwoju } \\
\text { gospodarczego }\end{array}$ & $\begin{array}{l}\text { Wartość } \\
\text { syntetycznego } \\
\text { miernika } \\
\text { rozwoju } \\
2013\end{array}$ & $\begin{array}{l}\text { Klasyfikacja } \\
\text { pod względem } \\
\text { stopnia rozwoju } \\
\text { gospodarczego }\end{array}$ \\
\hline mazowieckie & 0,436 & wysoki & 0,509 & wysoki \\
\hline małopolskie & 0,351 & średni wyższy & 0,359 & średni wyższy \\
\hline pomorskie & 0,343 & średni wyższy & 0,354 & średni wyższy \\
\hline zachodniopomorskie & 0,296 & średni wyższy & 0,336 & średni wyższy \\
\hline śląskie & 0,311 & średni wyższy & 0,335 & średni wyższy \\
\hline łódzkie & 0,240 & średni wyższy & 0,329 & średni wyższy \\
\hline dolnośląskie & 0,397 & wysoki & 0,305 & średni wyższy \\
\hline wielkopolskie & 0,305 & średni wyższy & 0,291 & średni wyższy \\
\hline kujawsko-pomorskie & 0,153 & średni niski & 0,221 & średni niski \\
\hline opolskie & 0,225 & średni niski & 0,191 & średni niski \\
\hline lubelskie & 0,140 & średni niski & 0,163 & średni niski \\
\hline lubuskie & 0,174 & średni niski & 0,162 & średni niski \\
\hline podlaskie & 0,106 & niski & 0,107 & niski \\
\hline warmińsko-mazurskie & 0,082 & niski & 0,099 & niski \\
\hline świętokrzyskie & 0,104 & niski & 0,093 & niski \\
\hline podkarpackie & 0,083 & niski & 0,091 & niski \\
\hline
\end{tabular}

Źródło: opracowanie własne na podstawie danych GUS. 


\section{Podsumowanie i wnioski}

Czołowe miejsca w rankingu rozwoju gospodarczego zajmują województwa: mazowieckie, małopolskie, pomorskie oraz zachodniopomorskie i w tych też województwach sektor usługowy skupia największą liczbę zatrudnionych - odpowiednio: $75,4 \%, 65,4 \%, 61,4 \%$ oraz $63,3 \%$. Wramach sektora usługowego w województwach mazowieckim, wielkopolskim i małopolskim stosunkowo duży odsetek osób znajduje zatrudnienie w sekcjach G-J związanych z handlem, transportem, gastronomią, hotelarstwem, informacją i komunikacją. W województwach przodujących w rozwoju gospodarczym zaobserwowano wzrost zatrudnienia w sektorze usługowym. W województwach mazowieckim, łódzkim i wielkopolskim przyrost zatrudnienia wystąpił w całym badanym okresie i wynosił odpowiednio $0,45,0,33$ i 0,48 p.p. W województwach małopolskim, pomorskim i dolnośląskim wzrost zatrudnienia w sektorze usługowym nastąpił dopiero od 2007 roku.

Mimo iż województwa śląskie i łódzkie zajmują 5 i 6 pozycję w rankingu rozwoju gospodarczego, to zatrudnienie w sektorze usług stanowi tam mniej niż $60 \%$ całkowitego zatrudnienia w gospodarce, a w województwie śląskim jest wręcz najniższe w skali całego kraju. Korzystny wydaje się fakt, że zatrudnienie w sektorze usługowym w tych województwach systematycznie wzrasta.

Na szczególną uwagę zasługują województwa lubelskie i podlaskie, które mimo niskiego poziomu rozwoju gospodarczego charakteryzują się ponad 66-procentowym udziałem zatrudnienia w sektorze usługowym. Niestety w województwie lubelskim zanotowano istotny spadek zatrudnienia w sektorze usługowym w latach 2005-2013, średnio o 0,16 p.p. z roku na rok. Województwa lubelskie i podlaskie skupiają też duży w skali kraju odsetek (ok. 60\%) zatrudnionych w sekcjach M-S sektora usługowego, czyli w sekcjach związanych między innymi z nauką (zaplecze B+R), edukacją, działalnością profesjonalną, naukową i techniczną oraz z opieką zdrowotną i pomocą społeczną. Duży odsetek pracujących w sekcjach M-S sektora usługowego (ponad 62\%) występuje również w województwach opolskim i warmińsko-mazurskim, które plasują się też pod koniec listy rankingowej rozwoju gospodarczego. Warto także zwrócić uwagę na to, że w ciągu 8 lat województwo lubelskie podniosło swą pozycję rankingową o jedno miejsce, warmińsko-mazurskie o dwa, zaś województwo podlaskie nie zmieniło go. Na podstawie powyższego podsumowania można więc postawić hipotezę, że województwa o stosunkowo niskim poziomie rozwoju gospodarczego stawiają na edukację, naukę, badania i rozwój, działalność profesjonalną, które są filarem GOW. Być może w przyszłości inwestycja w tę część 
sektora usługowego będzie skutkować wyższą pozycją tych województw w rozwoju gospodarczym.

Ogólne wnioski wynikające z przeprowadzonych analiz są następujące:

1. Największy odsetek zatrudnionych w sektorze usługowym występuje w województwach o wysokiej wartości syntetycznego miernika rozwoju gospodarczego.

2. Tempo przyrostu zatrudnienia w sektorze usługowym jest największe w województwach o wysokim poziomie rozwoju gospodarczego.

3. Województwa o niskim poziomie rozwoju gospodarczego charakteryzują się również dużym (ponad 66-procentowym) odsetkiem zatrudnionych w sektorze usługowym, przy czym ponad $60 \%$ zatrudnionych w tym sektorze znajduje pracę w sekcjach $\mathrm{M}-\mathrm{S}$.

\section{Literatura}

Jankowska, D., Majka, A. (2012). Transformation ofthree-sector structure of employment in Poland in 2004-2009. W: A. Jaeschke, W. Starzyńska (red.), Statistical Methods in Region and Social Analyses under Integration and Globalization (s. 111-130). Lodz: Statistical Office.

Jankowska, D. Majka, A. (2013). Zmiany na lokalnych rynkach pracy województwa podkarpackiego w aspekcie przeobrażeń trójsektorowej struktury zatrudnienia. W: J. Rymarczyk, M. Domiter, W. Michalczyk(red.), Integracja i kryzysy na lokalnych i globalnych rynkach we współczesnym świecie (s. 327-337). T. 1. Wrocław: Wyd. UE we Wrocławiu.

Kuczewska, L. (2007). Sektor usług w Polsce w Latach 2000-2004. Handel Wewnętrzny, $3,24$.

Kwiatkowski, E. (1980). Teoria trzech sektorów gospodarki. Prezentacja i próba oceny. Warszawa: PWN.

Nowak, E. (1990). Metody taksonomiczne w klasyfikacji obiektów społeczno-gospodarczych. Warszawa: PWE. 


\title{
CHANGES IN EMPLOYMENT IN THE SERVICE SECTOR VERSUS REGION'S ECONOMIC DEVELOPMENT
}

\begin{abstract}
This article attempts to answer the question if there is a relation between structure and dynamics of employment in the service sector and economic development of region. Linear trend models were used in order to define the changes that occurred in employment in services, whereas the level of development was estimated by using taxonomic method of grouping objects. Empirical numerical material came from Local Data Bank of Central Statistical Office and covered the years 2005-2013.
\end{abstract}

Translated by Dorota Jankowska, Agnieszka Majka

Keywords: economic development, employment, service sector, trend, taxonomic grouping JEL Codes: O10, O18, J21, J40, C10 